\title{
Determinants of Productivity Among Manufacturing Firms in South-Eastern Nigeria: Cobb-Douglas Stochastic Frontier Production Function Approach
}

\author{
NTO PHILIPS O.O, MBANASOR J.A \\ Michael Okpara University of Agriculture, Abia State, Nigeria \\ IGBERI CHRISTIANA O \\ Ebonyi State University, Abakaliki, Nigeria
}

\begin{abstract}
The paper examined the determinants of productivity among manufacturing firms in south-eastern Nigeria. The study adopted cross sectional data obtained from 120 manufacturing firms which were operational by 2011 production season. The data were analysed with Cobb-Douglas functional form of the stochastic frontier using FRONTIER 4.1 programme. The results indicated that the major determinants of productivity are amount spent on unskilled labour, cost of raw materials, and net productive asset with all exhibiting expected positive influence on productivity at $1 \%$ probability level respectively. Variables like registration status and years of operation have direct influence on the technical efficiency of the firm while size of firm had negative relationship with technical efficiency against conventional view. The mean technical efficiency level was $75 \%$ while about $76 \%$ of the firms operated above $60 \%$ technical efficiency level. The minimum and maximum technical efficiency levels were $13.36 \%$ and $96.7 \%$ respectively. In order to increase productivity, most of the manufacturing firms need to increase their efficiency level under their existing resources thereby enhancing their productivity. It is also recommended that manufacturing firms should increase their raw material input level through bulk purchase among others.
\end{abstract}

Keywords: determinants, productivity, south-eastern, Cobb-Douglas, frontier

\section{Introduction}

Improving productivity has become a key objective for manufacturing firms in Nigeria and other developing countries. Onyeranti (2012) outlined its roles in economic growth and development all over the world. Higher productivity among manufacturing firms is a sure means of boosting economic growth, enhancing firm growth and increasing standard of living of the people through large supplies of both consumer and capital goods at a lower costs and prices (Alao, 2010; Anyanwu, 2004; Nto \& Mbansor, 2011).

Productivity (which is defined as ratio of total result achieved over total resources consumed) has played

NTO PHILIPS O.O, Ph.D., Senior Lecturer, College of Agribusiness and Financial Management, Michael Okpara University of Agriculture.

MBANASOR J.A, Professor, College of Agribusiness and Financial Management, Michael Okpara University of Agriculture. IGBERI CHRISTIANA O, Lecturer, Department of Agricultural Economics, Management and Extension, Ebonyi State University.

Correspondence concerning this article should be addressed to NTO PHILIPS O.O, Department of Banking and Finance, Michael Okpara University of Agriculture, P.M.B. 7267, Umudike, Abia State, Nigeria. E-mail: nto2015@yahoo.com. 
significant roles in consolidating economies of both emerging and middle income countries through higher real earnings, improvements in working conditions and improved returns on asset (Uche, 1991). Nto and Mbanasor (2011) observed that enhanced productivity will equally contribute to the competiveness of manufacturing firms in both domestic and foreign market which is required to put Nigeria back on the path of economic recovery and growth. This is imperatively following the prolonged economic recession occasioned by the collapse of the world oil market from the early 1980 as well as global financial crisis that rocked all the manufacturing firms since 2007 (Onyeranti, 2012).

Although several economic measures have been introduced by government to address problems associated with productivity decline, but evidence abound that they have not yielded the desired results. For instance, contributions of manufacturing firms to the nation's Gross Domestic Product (GDP) have been on the declining trend, ranging from 9.2\% in 1981-1985 to 6.3\% in 1996-1998 (Anyanwu, 2004). A report by Manufacturers Association of Nigeria (MAN) confirmed that the general trend in productivity among manufacturing firms was negative in 1989. According to NBS (2012), the situation has not improved, though growth rate of manufacturing sector may have increased marginally from 7.31\% in 2010 to $7.32 \%$ in 2011, but an ugly scenario could be drawn when compared with 2008 and 2009 when growth rate was 8.39 and 8.13 percent respectively. With this statistical review of contribution of manufacturing sector to GDP, it is obvious that productivity among the manufacturing firms has not improved, hence, the need for an urgent and critical step that will help to identify major drivers of productivity among manufacturing firms in Nigeria.

Anyanwu (2004) reported that middle income countries like Hong Kong, South Korea, Singapore, the Philippines, India, Mexico, and Brazil which took similar steps and embraced boosting of productivity among manufacturing firms as an integral part of their national planning scheme have made significant in-roads into the world manufacturers' market. Also, Japan from the end of the World War II and the United States of America from the 1970s have made high productivity of the centre point of their economic development plans, and the results have been resounding. Nigerian scholars and researchers must borrow a leaf by bringing productivity to focus, if the country is to join the league of economically vibrant states following vision 20, 2020 project. This is true since increased productivity is the panacea to economic growth and development. Hence, the need for this study aimed at reviewing productivity among manufacturing firms in Nigeria, as it will help significantly if vicious cycle of poverty and unemployment is to be broken in Nigeria.

However, several studies' consultation may have given insight to the identification and measurement of major determinants of productivity, but the methodology used by some of them may have some shortcomings, and may give misleading results consequently, which cannot be used for policy formation. Such studies' consultation include Banker, Datar, and Kaplan (2012), which reported that measuring productivity involves ratio of total output to total inputs, i.e., quantity of output produced/quantity of inputs consumed.

This measure of physical productivity attempts to produce more outputs with fewer inputs while maintaining quality. However, Nto and Mbanasor (2011) observed that this method of measuring productivity cannot produce reliable meaning especially when comparing productivity at different periods or when comparing different facilities producing similar outputs. Also, this method did not contemplate the use of heterogeneous inputs in the production system, though, some authors suggested that this problem could be solved by adding up in "constant price" money values. The loophole in this approach is that the resultant productivity index will be economic productivity and not physical productivity which conveys more and better meaning to users (Iyanwura \& Osoba, 1983; David, 1972; and Onyeranti, 2012). Prasada-Rao, Timothy, and 
Allaudidin (2004) and Grosskopf (1993) asserted that productivity can be measured through non-parametric index number like growth accounting equation, division index, exact index, Törnqvist index, and malmquist productivity index. Onyeranti (2012) added that the notable shortcomings of the above approaches include biased estimates of productivity growth because of the prevalence of inefficiency. Also, the parameter to be estimated cannot be tested with econometric tools to determine level of significance (Nto \& Mbanasor, 2011).

In another development, several studies including Battese and Coelli (1995), Amornkitvikai and Harvie (2010), Msuya, Hisano, and Nariu (2008), Onyeranti (2012), Nto and Mbanasor (2011), Anyanwu (2004), Battese, Malik, and Gill (1996), and Ajibefun, Battese, and Daramola (2002) noted that to overcome the flaws of the above highlighted methods of estimating productivity among manufacturing firms, Stochastic Frontier Production Function(SFPF) presents a better approach for modelling the determinants of productivity. One important benefits of this approach is that its econometric implementation yields parameter estimates of the production technology in the process of measuring productivity advancement (Onyeranti, 2012). Also, the model addresses technical efficiency and recognises the fact that random shocks beyond producers' control may affect the production output. Therefore, in the model, the impact of random shocks (as labour or capital performance) on the product can be separated from the impact of technical efficiency variation (Constantin, Martin, \& Rivera, 2009).

A number of studies have used the stochastic frontier production function to identify and estimate the determinants of productivity in their areas of interest, and the results obtained were found adequate for policy formulation. For instance, Nto and Mbanasor (2011) in a study on "productivity in agribusiness firms and its determinants in Abia State, Nigeria” observed that the major determinants of productivity are skilled labour and raw materials. While skilled labour exerted positive influence on productivity with coefficient of 0.823 , cost of raw materials negatively influenced productivity among agribusiness firms in the area.

Akinlo (2006) explored the effects of macroeconomic factors on productivity in 34 sub-Saharan African countries for the period 1980-2002. The result indicated that external debt, inflation rate, lending rate among others negatively influenced productivity while human capital, credit to private sector as percentage of GDP, foreign direct investment as percentage of GDP, manufacturing value added as a share GDP have significant positive effect on productivity.

Msuya et al. (2008) in explaining the productivity variation among small holder maize farmers in Tanzania using SFPF discovered that the major determinants of productivity are low level of education of farmers, lack of extension services, limited capital, land fragmentation, and unavailability of inputs among others.

Constantin et al. (2009) in using Cobb-Douglas functional form of SFPF to analysed productivity of Brazilian agribusiness observed that significant variables that influence it are harvest area, credit, and lime stone with all assuming expected sign.

All these studies and their findings provided useful information for this study however not centred on the determinants of productivity among manufacturing firms in south-eastern Nigeria which is the nucleus of this study.

\section{Methodology}

The study was conducted in south-eastern Nigeria, one of the six geopolitical zones of the country comprising five states, namely, Abia, Anambra, Ebonyi, Enugu, and Imo. The zone has common boundaries with Cross River, Akwa Ibom, Benue, Kogi, Delta, Rivers, and Edo States. It has high clusters of 
manufacturing firms around Aba, Owerri, Nnewi, Onisha, Umuahia, Awka, Enugu, Abakaliki, and Ohafia cities.

The cross sectional data used for the study were collected from 120 formal manufacturing firms. The procedures adopted in the selection of the firms were through fact finding visits to offices of Manufacturing Association of Nigeria, Abuja as well as Chamber of Commerce, Industry, Mines, and Agriculture at Aba and Enugu where list of registered manufacturing firms was obtained. Purposive sampling techniques were adopted to select at least 50 firms from each of the five states after the preliminary visit of firms in the states to validate the list and also to eliminate moribund firms. The next stage was the use of random sampling technique to select 120 firms from the zone. A well structured and pre-tested questionnaire was used to collect data for 2010/2011 production season from each of the firms. The variables covered, include output of the firm, inputs used, raw materials, registration status of the firm, years of operation, size of firm, and other firm specific characteristics.

To achieve the objectives of the study, specific characteristics of the sampled firms were realised with simple descriptive statistics while determinants of productivity were analysed with Cobb-Douglas functional form of the stochastic frontier production model. This model is chosen because of its flexibility and simplicity in computation. Also, its output can be directly treated as elasticity hence increase in any factor of production like capital or labour or both by a factor $N$ will also increase output by a factor "N". Where "N" is the multiplier. Following Aigner, Lovell, and Schmidt (1977) and Battese and Coelli (1995), the model is explicitly specified thus:

$$
\operatorname{In}\left(Y_{i}\right)=\alpha_{0}+\alpha_{1} \operatorname{In}\left(X_{1}\right)+\alpha_{2} \operatorname{In}\left(X_{2}\right)+\alpha_{3} \operatorname{In}\left(X_{3}\right)+\alpha_{4} \operatorname{In}\left(X_{4}\right)+\alpha_{5} \operatorname{In}\left(X_{5}\right)+\alpha_{6} \operatorname{In}\left(X_{6}\right)+V_{i}+U_{i}
$$

where:

$\alpha_{0}-\alpha_{6}$ are the estimated parameter;

In = Natural logarithm;

$\mathrm{Y}=$ Output of the manufacturing firm (Naira), deflated by the manufacturing producer price index (PPI) of firm ith;

$\mathrm{X}_{1}=$ Expenses on skilled labour (Naira) deflated by the PPI;

$\mathrm{X}_{2}=$ Expenses on unskilled labour (Naira) deflated by PPI;

$\mathrm{X}_{3}=$ Net productive fixed assets deflated by PPI of capital goods of firm $i$ th;

$\mathrm{X}_{4}=$ Major raw materials (Naira) deflated by PPI;

$\mathrm{X}_{5}=$ Expenses on rent for the firm $i$ (Naira);

$\mathrm{X}_{6}=$ Expenses of gasoline (Naira);

$\mathrm{V}_{\mathrm{i}}=$ Random error;

$\mathrm{U}_{\mathrm{i}}=$ Non-negative random variable (or technical inefficiency).

The term $\mathrm{V}_{\mathrm{i}}$ is a symmetric error, which account for random variations in output due to factors beyond the control of the firm manager like weather/climatic change, breakdown of machinery, fire outbreak, strike by workers, civil commotion etc.. The inefficiency effects model was formulated and estimated jointly with the Cobb-Douglas stochastic frontier model in a single stage maximum likelihood estimation procedure using the computer software Frontier Version 4.1 (Coelli, 1996). The technical inefficiency model is explicitly written as follows: 


$$
\mathrm{U}_{\mathrm{i}}=\sigma_{0}+\sigma_{1} \mathrm{q}_{1}+\sigma_{2} \mathrm{q}_{2}+\sigma_{3} \mathrm{q}_{3}+\sigma_{4} \mathrm{q}_{4}+\sigma_{5} \mathrm{q}_{5}+\mathrm{W}_{\mathrm{i}}
$$

$\sigma_{0}-\sigma_{5}=$ Coefficient to be estimated;

$\mathrm{q}_{1}=$ Area of operation ( 0 = rural, 1 = urban);

$\mathrm{q}_{2}=$ Registration status (Sole proprietorship $=0$, otherwise $=1$ );

$\mathrm{q}_{3}=$ Size of firm (Naira);

$\mathrm{q}_{4}=$ Origin of firm ( 0 = Inherited, $1=$ Started by owner $)$;

$\mathrm{q}_{5}=$ Years of operation (years);

$\mathrm{W}_{\mathrm{i}}=$ Random error.

\section{Results and Discussions}

\section{Classification of Sampled Manufacturing Firms in South-Eastern Nigeria}

According to Table 1, majority of the sampled firms (33.33 percent) are into manufacturing of consumer products. Such firms are involved in the production of fashion, home and office products, purified drinking water as well as personal and pharmaceutical products.

Table 1

Classification of Sampled Manufacturing Firms

\begin{tabular}{lcc}
\hline Types of manufacturing firms & Frequency & Percentage \\
\hline Agro and food industry & 36 & 30.00 \\
Consumer products & 40 & 33.33 \\
Industrial materials & 16 & 13.33 \\
Publishing & 4 & 3.33 \\
Construction material & 24 & 20.00 \\
Technological/Electronic & 0 & 0 \\
Total & 120 & 100 \\
\hline
\end{tabular}

Note. Source: Field survey data, 2012.

Table 1 also indicated that 30 percent of the firms are involved in agro and food industry. According to Amornkitvikai and Harvie (2010) such firms are agribusiness and are involved in food and beverage processing. Also the Table depicted that 24 and 16 percents of the sampled firms were into building construction materials and industrial materials respectively. The industrial materials include those into packaging, paper and printing materials as well as petrochemical and chemical products. These materials are not end products but are used for further production.

\section{Average Statistics of Sampled Manufacturing Firms in South-Eastern Nigeria}

The average statistics of sampled manufacturing firms in South-Eastern Nigeria are presented in Table 2. On the average, a typical manufacturing firm in the study area produces output with about $\$ 48,000,000$. According to the table, the average amount spent on the factors employed in the production are skilled labour ( $\$ 5,108,333)$, unskilled labour ( $\$ 1,592,600)$, net productive asset ( $\$ 921,200)$, major raw materials ( 20,700,000) and Expenses on Gasoline was $\$ 2,092,467$. The large amount spent on gasoline is due on the factory energy generation considering epileptic power supply in Nigeria. The implication is that an average manufacturing firm spends on major factor inputs, the sum of $\$ 29,585,500$ to produce output of $448,000,000$.

Table 2 also indicated that 72 percent of the sampled firms operated in the urban area while 56.64 percent registered as sole proprietorship. Also, the average size of firm is $\$ 52,800,000$. Following the registration 
status and size of firm, it is clear that most of the manufacturing firms in the study area are small and medium scale enterprises. Table 2 also revealed that $96.62 \%$ of the manufacturing firms were started owners themselves. Hence, only 3.37\% inherited the firms from parents and other relations. Table 2 also shows that the firms have averagely operated for 7.6 years. The large number of respondents starting the firms by themselves and the low number of years of operation point to the fact that Nigeria is still an emerging economy.

Table 2

Average Statistics of Manufacturing Firms in South-Eastern Nigeria

\begin{tabular}{lllll}
\hline Variables & Mean value & Minimum value & Maximum value & Std. deviation \\
\hline Output (\#) & $48,000,000$ & 700,000 & $8.88 \mathrm{e}+08$ & $1.65 \mathrm{e}+08$ \\
Skilled labour (\#) & $5,108,333$ & 50,000 & $7.00 \mathrm{e}+08$ & $1.52 \mathrm{e}+07$ \\
Unskilled labour (\#) & $1,592,600$ & 48,000 & $1.80 \mathrm{e}+07$ & 3224520 \\
Net productive asset (\#) & 921,200 & 30,000 & $1.30 \mathrm{e}+07$ & 2375131 \\
Raw materials (\#) & $20,700,000$ & 540,000 & $3.00 \mathrm{e}+08$ & $5.96 \mathrm{e}+07$ \\
Rent (\#) & 904,000 & 70,000 & $1.00 \mathrm{e}+07$ & 1915345 \\
Exp. on gasoline (\#) & $2,092,467$ & 120,000 & $1.80 \mathrm{e}+07$ & 3500609 \\
Size of firm (\#) & $52,800,000$ & 800,000 & $8.00 \mathrm{e}+08$ & $1.52 \mathrm{e}+08$ \\
Area of operation (\%) (Urban area) & $72 \%$ & - & - & - \\
Registration status (\%) (Sole proprietorship) & 56.64 & - & - & - \\
Origin of firm (\%) (Started by owner) & $96.62 \%$ & - & - & - \\
Year of operation & 7.616667 & 3 & 25 & 3.979323 \\
\hline
\end{tabular}

Note. Source: Calculated from Field Survey Data, 2012.

\section{Determinants of Productivity Among Manufacturing Firms in South-Eastern Nigeria}

The maximum likelihood (ML) estimates of the Cobb-Douglas Production Parameter for manufacturing firms are presented in Table 3. Only coefficients of unskilled labour, net productive assets and major raw materials show significant effect on output of the firms. The variables had the expected positive influence at 1 percent probability level. By implication, increase in unskilled labour $\left(\mathrm{X}_{2}\right)$, net productive asset $\left(\mathrm{X}_{3}\right)$, and major raw materials $\left(\mathrm{X}_{4}\right)$ will lead to increase in output, thus productivity. The result is consistent with expected view that when factors of production increase, output will also increase thereby enhancing productivity.

Table 3

Estimated Cobb-Douglas Stochastic Frontier Production Functions for Manufacturing Firms in South-Eastern Nigeria

\begin{tabular}{|c|c|c|c|}
\hline Variable & Coefficient & Std. error & $T$-value \\
\hline Constant $\mathrm{X}_{0}$ & -0.8364 & 0.8662 & 1.09589 \\
\hline Skilled labour $\mathrm{X}_{1}$ & 0.0623 & 0.0614 & 1.0417 \\
\hline Unskilled labour $\mathrm{X}_{2}$ & 0.2512 & 0.0689 & $3.6431^{* * *}$ \\
\hline Net productive assets $\quad \mathrm{X}_{3}$ & 0.4005 & 0.1022 & $4.8013^{* * *}$ \\
\hline Major raw materials $\mathrm{X}_{4}$ & 0.5142 & 0.0876 & $5.8667^{* * *}$ \\
\hline Rent $\mathrm{X}_{5}$ & 0.0006 & 0.0003 & 0.0062 \\
\hline $\begin{array}{l}\text { Expenses on gasoline } X_{5} \\
\text { Efficiency factors }\end{array}$ & -0.0892 & 0.0828 & -1.0766 \\
\hline Constant $\left(\mathrm{q}_{0}\right)$ & -1.8284 & 0.5706 & $-3.2043^{* * *}$ \\
\hline Area of operation $\left(\mathrm{q}_{1}\right)$ & 0.4466 & 0.3133 & 1.4255 \\
\hline Registration status $\left(\mathrm{q}_{2}\right)$ & 1.6837 & 0.3022 & $5.5713^{* * *}$ \\
\hline Size of firm $\left(\mathrm{q}_{3}\right)$ & $3.4613 \times 10^{-8}$ & $2.0573 \times 10^{-8}$ & $-1.6989^{*}$ \\
\hline Origin $\left(\mathrm{q}_{4}\right)$ & 0.1436 & 0.42358 & 0.3390 \\
\hline
\end{tabular}


(Table 3 continued)

\begin{tabular}{lccc}
\hline Variable & Coefficient & Std. error & $T$-value \\
\hline Years of operation $\left(\mathrm{q}_{5}\right)$ & 0.2588 & 0.0481 & $5.3835^{* * *}$ \\
Diagnostic statistics & & & - \\
Log likelihood & 98.8355 & - & $5.3375^{* * *}$ \\
Sigma squared $\left(\sigma^{2}\right)$ & 0.5472 & 0.0651 & $3.4887^{* * *}$ \\
Gamma $(\gamma)$ & 0.2363 & 0.0677 & - \\
Likelihood ratio test & 69.6368 & - & , \\
\hline Notes. Source: Calculated from Field Survey Data, 2012. ${ }^{*},{ }^{* *}{ }^{* * * *}$ Means Significant at $10 \%, 5 \%$ level of probability \\
respectively.
\end{tabular}

A more employment of these factors of production by the firm is an indication of output growth. The result is consistent with those obtained Nto and Mbanasor (2011), Onyenweaku and Okoye (2007), and Onyenweaku and Effiong (2005).

Table 3 also indicated the estimated parameter of the determinants of technical efficiency of the manufacturing firms. Among the variables specified in the model, registration status, years of operation and size of firms were statistically significant.

The coefficient of registration status was positively significant at one percent probability level. This implies that firms which registered with more than one membership such as partnership, Limited Liability Company, public liability company are more technically efficient than sole proprietorship. This is in line with apriori expectation following the saying that "two heads are better than one". Besides, partnership, Limited Liability Company and public liability company have better access to credit and more ability to raise fund from members than sole proprietorship. The coefficient of years of operation was also directly related to technical efficiency. Increase in the number of years of operation will lead to higher technical efficiency. As years of operation increase, firm managers acquire more experience on how to combine production resources so as to increase technical efficiency thus productivity increase (Nto \& Mbanasor, 2011).

The coefficient of size of firm is negatively related to technical efficiency of the manufacturing firm. This is contrary to a priori expectation. However, the results may have pointed to diseconomies of scale arising from under-utilization of firm size. Most large firms are under-utilized in Nigeria because of lack of access to credit to support production activities.

Following the procedures of Msuya et al. (2008), the validity of the model which jointly tested the parameters of both determinants of productivity and technical efficiency was performed. These various tests of null hypothesis for the parameters in the frontier production function and in the inefficiency models are performed using generalized likelihood ratio (LR) test statistics defined by: $\gamma=2\left\{\log \left(\mathrm{L}_{\left(\mathrm{H}_{0}\right)}\right) \log \left(\mathrm{L}\left(\mathrm{H}_{1}\right)\right\}\right.$, where $\mathrm{L}\left(\mathrm{H}_{0}\right)$ and $\mathrm{L}\left(\mathrm{H}_{1}\right)$ denote the values of the likelihood function under the null $\left(\mathrm{H}_{0}\right)$ and alternate $\left(\mathrm{H}_{1}\right)$ hypothesis respectively. If the null hypothesis is true, the LR test statistic has an appropriate chi-square or mixed chi-square distribution with degree of freedom equal to the difference between the number of parameters in the unrestricted and restricted models. The test that null hypothesis $\mathrm{H}_{0}: \gamma=0$ which specifies that the technical inefficiency effects are not present in the model as the manufacturing firms are efficient and have no room for efficiency growth is rejected. This follows a gamma parameter of 0.237 which is significant at one percent probability level meaning that about 23.7 percent of the disturbance terms are due to inefficiency. This confirms the relevance of including $\mathrm{V}_{\mathrm{i}}$ in the models, which determines 23.7 percent of the total variation in output of manufacturing firm. The reliability and goodness of fit of the model is also authenticated by the high 
livelihood ratio of 69.63 as well as high and significant coefficient of sigma square $\left(\delta^{2}=0.547\right)$. The Cobb-Douglas Frontier production function which included technical efficiency term is therefore adequate and correctly specified the distribution assumptions of the composite error term.

The frequency distribution of technical efficiency among manufacturing firms were identified and presented in Table 4. Individual technical efficiency indices range between 13.36 percent and 96.7 percent with a mean of 75 percent. About 76 percent of the firms have technical efficiency indices of above 60 percent. Following Onyenwaku and Okoye (2007), the high levels of technical efficiency obtained in this study are consistent with the low variance of the firm effects.

Table 4

Frequency Distribution of Technical Efficiency Among Manufacturing Firms in South-Eastern Nigeria

\begin{tabular}{lcc}
\hline Technical efficiency range & Frequency & Percentage \\
\hline $0.00-0.20$ & 4 & 3.33 \\
$0.21-0.40$ & 4 & 3.33 \\
$0.41-0.60$ & 20 & 16.66 \\
$0.61-0.80$ & 20 & 16.66 \\
$0.81-1.00$ & 72 & 59.99 \\
Total & 120 & 100 \\
\hline Mean & $75 \%$ & \\
Maximum & $96 \%$ & \\
Minimum & $13 \%$ & \\
\hline
\end{tabular}

Note. Source: Calculated from Field Survey Data, 2012.

\section{Conclusions}

The study focused on the determinants of productivity among manufacturing firms in south-eastern Nigeria. It employed Cobb-Douglas production function in the analysis of data. The study revealed that the major determinants of productivity are unskilled labour, raw materials, and net productivity assets. The variables which affect technical efficiency level of the firms are registration status, years of operation, and size of firm. The positive relationship between raw materials and productivity points to the need for firms to embark on bulk purchase as well as engaging in backward integration with major suppliers of their raw materials, so as to ensure constant and adequate supply. The result on registration status emphasizes the need for government of Nigeria to design policies that will enforce multiple memberships during manufacturing company registration. Also, cooperative structure of production is also recommended among manufacturing firms in Nigeria. Furthermore, the inverse relationship obtained between firm size and productivity, calls for further research on the appropriate size of firm that will enable manufacturing firms produce output at high technical efficiency.

\section{References}

Aigner, D. J., Lovell, C. A. K., \& Schmidt, P. J. (1977). Formulation and estimation of stochastic frontier production function models. Journal of Econometrics, 6, 21-37.

Ajibefun, A. A., Battese, G. E., \& Daramola, A. G. (2002, July). Analysis of policy issues in technical efficiency of small scale farmers using the stochastic frontier production function: With application to Nigerian farmers. Paper presented at the International Farm Management Association Congress, Wasenningen, Netherland.

Akinlo, A. E. (2006). Macroeconomic factors and total factor productivity in Sub-Saharan African countries. International Research Journal of Finance and Economics, 1, 1450-2887. 
Alao, R. O. (2010). Productivity in the Nigeria manufacturing sub-sector: An error correction model (ECM). European Journal of Economics, Finance and Administrative Sciences, 20, 26.

Amornkitvikai, Y., \& Harvie, C. (2010). Identifying and measuring technical efficiency factors: Evidence from unbalanced panel data for Thai Limited Manufacturing Enterprises (Faculty of Commerce-Economic Working Paper, University of Wollongong, pp. 1-35).

Anyanwu, C. M. (2004). Productivity in the manufacturing industry (Research Department, Central Bank of Nigeria, pp. 124-135).

Banker, R. D., Datar, S. M., \& Kaplan, R. S. (2012). Productivity measurement and management accounting. Journal of Accounting, Auditing and Finance, 5, 528-554.

Battese, G. E., \& Coelli, T. J. (1995). A model for technical inefficiency effects in stochastic frontier production function for panel data. Empirical Economics, 20, 325-332.

Battese, G. E., Malik, S. J., \& Gill, M. A. (1996). An investigation of technical efficiency of production of wheat farmers in Four district of Pakistan. Journal of Agricultural Economics, 47(1), 37-49.

Coelli, V. J. (1996). Guide to Frontier Version 4.1: A computer program for cost function estimation (Department of Economics, University of New England, Armidale Australia).

Constantin, P. D., Martin, D. L., \& Rivera, E. B. B. R. (2009, July-December). Cobb-Douglas, transom stochastic production function and data envelopment analysis in total factor productivity in Brazilian Agribusiness. The Flagship Research Journal of International Conference of the Production and Operations Management Society, 2(2), 20-33.

David, L. S. (1972). International Encyclopaedia of the Social Sciences (Reprint ed.), 12, 522-536.

Grosskopf, S. (1993). Efficiency and productivity in Fried HO, Knox CLL and Shelton S.S. The measurement of productivity efficiency: Technique and application (pp. 160-194). New York: Oxford University Press.

Iyanwura, O., \& Osoba, A. M. (1983). Measuring productivity, conceptual and statistical problems: Improvement of statistics. In A. M. Osoba (Ed.), Productivity in Nigeria, Processing of a National Conference. Ibadan: NISER.

Msuya, E. E., Hisano, S., \& Nariu, T. (2008). Explaining productivity variation among smallholder maize farmers in Tanzania (pp. 1-31). Paper presented in the xii World Congress of rural Sociology Association, Goyang, Korea.

National Bureau of Statistics (NBS). (2012). 2010 and Q1-Q2, 2011 Gross Domestic Product for Nigeria (pp. 1-14). Abuja, Nigeria: Publication of NBS.

Nto, P. O. O., \& Mbanasor, J. A. (2011). Productivity in agribusiness firms and its determinants in Abia State, Nigeria. Journal of Economics and International Finance, 3(12), 662-668.

Onyenweaku, C. E., \& Effiong, E. O. (2005). Technical efficiency in pig production in Akwa Ibom State, Nigeria. Journal of Sustainable Tropical Agricultural Research, 6, 51-57.

Onyenweaku, C. E., \& Okoye, B. C. (2007). Technical efficiency of small holders cocoyam farmers in Anambra State, Nigeria: A translog stochastic frontier production function approach. International Journal of Agriculture and Rural Development, 9(1), $1-5$.

Onyeranti, G. A. (2012). Concept of measurement of productivity (Department of Economics, University of Ibadan).

Prasada-Rao, D. S., Timothy, J. C., \& Allaudidin, M. (2004). Agricultural productivity growth, employment and poverty in developing countries 1970-2000 (Employment Strategy Paper, Employment Trend Units, Employment Strategy Department).

Sangosanya, A. O. (2011). Firms growth dynamics in Nigeria and manufacturing industry: A panel analysis. Journal of Applied Econometric Review, 1(1), 3-10.

Uche, E. O. N. (1991). Public service productivity. In P. O. C. Umeh et al. (Eds.), Increasing productivity in Nigeria (pp. 63-75). Proceedings of the First National Conference on Productivity 1st-3rd December, 1987, National Productivity Centre, Macmilla, Nigeria. 